\title{
PERBANDINGAN PEMBERIAN BUFFERED PEHAKAIN DENGAN FRESHLY MIXED LIDOKAIN- EPINEFRIN PADA PERSEPSI NYERI KARENA INFILTRASI ANESTESI LOKAL
}

\author{
Ratih Pramuningtyas \\ Bagian Ilmu Kesehatan Kulit dan Kelamin \\ Fakulas Kedokteran Universitas Muhammadiyah Surakarta \\ Correspondence to : dr. Ratih Pramuningtyas, Sp.KK \\ Email : Pramuningtyas_dr@yahoo.com
}

\begin{abstract}
Over the last decade, there has been a rise in the number of surgical procedures being perfomed under local anethesia. The infiltration of the local anesthetic is the most painful part of this procedures, and pain associations can develop into avoidance behaviors in future procedures. Several techniques were used to reduce the pain of local anesthetic infiltration. The objective of this study is comparing the effect of Buffered Pehacaine versus freshly mixed lidocaine-epinephrin in reducing the pain of local anesthetic infiltration. Six subject were recruited for this study. Each subject was received 2 kind of treatment. Subject rated pain using Visual Analog Score. Pain score were compared using paired t test. Sixty seven percent (67\%) subjects reported that pain of infiltration was lower in Buffered pehacaine than freshly mixed lidocaine-epinephrine. The difference was not statistically significant. There are no significant difference between Buffered Pehacaine versus freshly mixed lidocaine-epinephrin in reducing the pain of local anesthetic infiltration
\end{abstract}

Keywords : local anesthetic infiltration, lidocaine, pehacaine

\section{PENDAHULUAN}

Beberapa tahun terakhir ini, terdapat peningkatan prosedur tindakan yang dilakukan dengan anestesi lokal (Leff et al, 2007). Hampir seluruh prosedur bedah kulit dilakukan dengan anestesi lokal, dan membutuhkan kepatuhan pasien agar berhasil (Shahwan, 2012). Infiltrasi dari anestesi lokal adalah bagian yang paling nyeri pada prosedur tersebut, dan nyeri akan menyebabkan reaksi penolakan pada prosedur tindakan berikutnya (Leffet al, 2007 dan Shahwan, 2012). Mekanisme munculnya nyeri ini diduga berhubungan dengan asiditas larutan larutan anestesi. Larutan anestesi lokal dibuat asam untuk meningkatkan kelarutan dan memperpanjang masa simpan. Kebanyakan dermatologis menggunakan lidokain dengan ditambahkan epinefrin ke dalamnya untuk memperpanjang waktu paruh obat, mengurangi toksisitas, dan menjaga hemostasis (Burns et al, 2005).

Beberapa teknik digunakan untuk mengurangi nyeri infiltrasi anestesi lokal termasuk menambahkan larutan buffer/penyangga berupa sodium bikarbonat pada larutan anestesi, mencampurkan lidokain dengan epinefrin sesaat sebelum penyuntikan, memanaskan larutan anestesi, teknik pengalihan, mengaplikasikan topikal analgesia sebelum infiltrasi dan local external cooling (Leff et al, 2007 dan Shahwan, 2012). Lidokain (dengan atau tanpa epinefrin) yang ditambahkan sodium bikarbonat sebagai larutan penyangga sampai mencapai $\mathrm{pH} 7.0$ - 7.4 telah dibuktikan lebih tidak menimbulkan nyeri dibandingkan yang tidak ditambahkan larutan penyangga, atau, beberapa dokter baru mencampur epinefrin dan lidokain pada saat akan digunakan (Burns et al, 2005).

Tujuan dari penelitian pendahuluan ini adalah untuk membandingkan efektifitas buffered pehakain denganfreshly mixedlidokainepinefrin sesaat sebelum tindakan anestesi untuk mengurangi nyeri karena infiltrasi larutan anestesi lokal pada kulit. 


\section{METODE PENELITIAN}

Penelitian ini merupakan penelitian deskriptif analitik untuk membandingkan buffered pehakain dengan freshly mixed lidokain epinefrin. Enam subjek diikutkan dalam penelitian ini. Sebelumnya pasien diberikan informed consent mengenai prosedur tindakan yang akan dikerjakan. Pasien hamil,pasien yang diketahui memiliki alergi terhadap obat anestesi lokal, dan pasien dengan gangguan sensasi tidak diikutkan dalam penelitian ini. Masing-masing subjek mendapatkan 2 macam perlakuan, yaitu pemberian pehakain yang diberi larutan penyangga sodium bicarbonat (buffered pehakain) dan lidokain yang ditambahkan epinefrin sesaat sebelum tindakan (freshly mixed).

Pada penelitian, larutan anestesi lokal yang dipersiapkan adalah pehakain dengan larutan penyangga, dengan mencampurkan pehakain berisi lidokain $\mathrm{HCL} 1 \%$ dan epinefrin dengan natrium bikarbonat $8,4 \%$ dengan perbandingan 10 : 1. Dalam hal ini sebanyak $1 \mathrm{ml}$ natrium bikarbonat ditambahkan dalam $10 \mathrm{ml}$ pehakain. Sedangkan untuk freshly mixed lidokain-epinefrin, lidokain Hcl 1\% ditambahkan epinefrin 1:100.000 dengan cara menambahkan $0,1 \mathrm{ml}$ epinefrin $1: 1000 \mathrm{ke}$ dalam $10 \mathrm{ml}$ lidokain HCL 1\%. Pada masingmasing perlakuan diberikan injeksi sebanyak 0,1 $\mathrm{ml}$ menggunakan spuit $1 \mathrm{cc}$ dengan ukuran jarum 27 gauge dalam 5 detik.Jarak antara 2 lokasi penyuntikan minimal $3 \mathrm{~cm}$.

Injeksi dilakukan secara intradermal, dengan sudut $15^{\circ}$. Subjek diminta untuk mengabaikan nyeri karena masuknya jarum. Untuk membedakan nyeri antara masuknya jarum dengan infiltrasi larutan anestesi lokal, diberikan jeda waktu selama 10 detik antara masuknya jarum dengan infiltrasi cairan. Nyeri karena infiltrasi larutan anestesi lokal diukur segera setelah injeksi menggunakan visual analog scale (VAS) dengan skala antara $0-100$. Sebelumnya pasien telah di edukasi cara mengukur nyeri menggunakan VASdimana 0 berarti tidak nyeri dan 100 nyeri paling buruk yang pernah dirasakan.Skor nyeri dari masing-masing penelitian akan diuji secara statistik menggunakan menggunakan paired t test dengan nilai signifikasi $\mathrm{p}<0,05$.

\section{HASIL PENELITIAN}

Pada penelitian mengenai perbandingan pehakain yang ditambahkan natrium bikarbonat dengan freshly mixed lidokain-epinefrin, dilakukan pada 6 subjek sehat berusia antara 25 - 40 tahun, semua berjenis kelamin laki-laki dengan tingkat pendidikan terakhir SMA. Subjek merupakan pasien poli kulit dan kelamin RS. Dr. Moewardi yang membutuhkan tindakan menggunakan anestesi lokal.Penyuntikan dilakukan pada lengan kanan dan kiri bagian volar dimana subjek tidak mengetahui isi larutan yang diinjeksikan. Adapun hasil VAS untuk pengukuran nyeri dapat dilihat pada Tabel 1

Tabel 1. Skor Nyeri Menggunakan VAS Pada Infiltrasi Buffered Pehakain dan Freshly Mixed Lidokain-Epinefrin

\begin{tabular}{ccc}
\hline Subjek & Buffered Pehakain & $\begin{array}{c}\text { Freshly mixed } \\
\text { lidokain+epinefrin }\end{array}$ \\
\hline A & 10 & 30 \\
B & 10 & 20 \\
C & 0 & 10 \\
D & 10 & 0 \\
E & 0 & 0 \\
F & 0 & 10 \\
Rata-rata & 5 & 11,7 \\
\hline Median & 5 & 10 \\
\hline
\end{tabular}

Hasil dari VAS menunjukkan bahwa 4 pasien melaporkan penggunaan freshly mixed lidokainepinefrin lebih nyeri dibandingkan buffered pehakain, 1 orang melaporkan sebaliknya, sisanya memberikan skor yang sama. Rata-rata skor nyeri \pm standar deviasi pada penggunaan buffered pehakain adalah $5+5,4$ sedangkan rata-rata skor nyeri \pm standar deviasi freshly mixed lidokainepinefrin adalah $11,7+11,7$. Perbedaan secara statistik antara nilai rata-rata kedua perlakuan diatas menggunakan paired $t$ test tidak signifikan $(\mathrm{p}=0,349)$.

Anestesi kulit yang efektif merupakan komponen yang penting pada bedah kulit. Penggunaan anestesi lokal saat ini memberikan efek anestesi yang diperlukan untuk berbagai prosedur diagnostik dan terapi dalam dermatologi dan menghindari risiko yang terkait dengan anestesi umum. Anestesi lokal bekerja dengan cara menghambat influksnatrium yang menghasilkan potensial aksi. Teknik anestesi lokal yang sering digunakan pada bedah kulit adalah Infiltrasi lokal. Agen anestesi dapat disuntikkan secara intradermal maupun subkutan (Willey and Lee, 2007).

Infiltrasi dari anestesi lokal merupakan bagian yang paling nyeri dari prosedur anestesi lokal (Shahwan, 2012). Nyeri tersebut sebagian 
besar disebabkan oleh kadar keasaman obat. Cairan dengan $\mathrm{pH}$ yang rendah menyebabkan nyeri karena sensasi terbakar yang ditimbulkan saat di infiltrasikan ke dalam jaringan karena iritasi. Selain itu pada $\mathrm{pH}$ yang rendah, bentuk obat aktif menurun, berdifusi bebas, menyebabkan onset anestesi yang memanjang (Burns et al, 2005). Larutan lidokain dan epinefrin di buat dalam suasana asam agar meningkatkan kelarutan dan stabilisasinya (Shahwan, 2012). Mengurangi nyeri saat infiltrasi anestesi jelas memberikan keuntungan mengurangi ketidaknyamanan pasien (Bartfield et al, 1995).

Beberapa metode telah ditemukan untuk mengurangi nyeri saat infiltrasi larutan anestesi lokal, dengan teknik yang berhubungan dengan larutannya atau tidak berhubungan dengan larutan anestesi lokal. Teknik yang digunakan dan berhubungan dengan larutan anestesi antara lain menambahkan larutan penyangga, mencampurkan lidokain dengan epinefrin sesaat sebelum injeksi, dan memanaskan larutan anestesi. Atau, teknik yang tidak berhubungan dengan larutan anestesi itu sendiri seperti teknik distraksi, aplikasi anestesi topikal sebelum injeksi anestesi lokal, dan penggunaan local external cooling (Shahwan, 2012).

Nyeri ditransmisikan dari kulit menuju gangglion dorsalis melalui 2 macam serabut saraf. Serabut saraf $\delta A$ merupakan serabut saraf termielinasi dan mengirimkan sinyal yang berhubungan dengan nyeri akut secara cepat, terutama berhubungan dengan dingin dan tekanan. Serabut saraf tipe $\mathrm{C}$ tidak termielinisasi dan mengirimkan rangsangan nyeri kronis dan gatal (Willey and Lee, 2007 and Henning, 2010). Anestesi lokal menunjukkan efek klinisnya pada saraf perifer dengan penghambatan sementara masuknya ion natrium yang diperlukan untuk membangkitkan dan propagasi potensial aksi melalui membran sel saraf, sehingga mencegah konduksi impuls saraf.Efek anestesi berasal dari interaksi kompleks pada lokasi yang spesifik pada voltage-gated saluran ion natrium yang menghasilkan inhibisi impuls listrik (Willey and Lee, 2007).

Nyeri adalah sensasi yang subjektif dan sulit untuk diukur. skala penilaian nyeri berguna untuk mengukur respon dari pasien tentang nyeri atau ketidaknyamanan mereka dan sering kali digunakan untuk mengukur intensitas nyeri yang dirasakan selama prosedur intervensi. Manfaat relatif dari skala nyeri VAS yang sering digunakan untuk menilai nyeri telah diteliti dengan baik, dan manfaatnya telah divalidasi oleh beberapa peneliti (Gursoy et al, 2007).

Pada penelitian ini, nyeri akibat infiltrasi cairan anestesi dikurangi dengan berbagai metode.

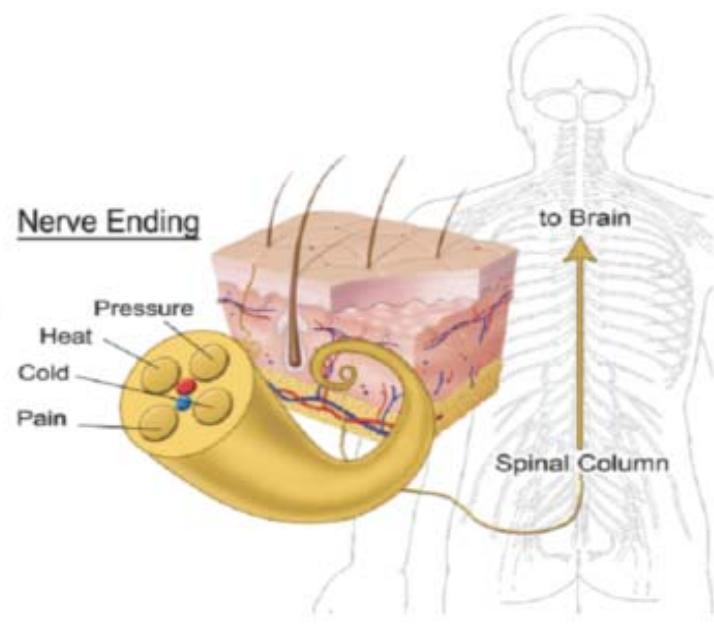

Gambar 1. Sebuah akhiran saraf bebas, menggambarkan 4 protein transmembran untuk panas, nyeri, dingin, dan getaran pada saraf tunggal

Penelitian ini dilakukan untuk membandingkan 2 metode untuk mengurangi nyeri infiltrasi anestesi lokal yang berhubungan dengan larutan anestesinya, yaitu membandingkan pehakain yang ditambahkan dengan larutan penyangga (buffered pehakain) dengan lidokain yang dicampur dengan epinefrin sesaat sebelum injeksi (freshly mixed).Anestesi lokal bekerja dengan menghalangi pembukaan saluran natrium dalam membran sel akson. Hal ini mencegah natrium memasuki sel saraf. Sel saraf tidak mengalami depolarisasi dan akibatnya potensial aksi diblokir. Bentuk kationik dari anestesi akan mengikat reseptor dalam saluran natrium (Hruza, 2008).

Anestesi lokal merupakan basa lemah, dimana, agar bersifat larut dalam air dan dapat disuntikkan membutuhkan penambahan garam hidroklorida. Dalam larutan, garam akan menyeimbangkan bentuk terionisasi dan tak terionisasi. Bentu terionisasi larut dalam air, memungkinkan injeksi jaringan. Sedangkan bentuk tak terionisasi, larut dalam lemak, berdifusi melalui jaringan menuju membran sel saraf, dimana kation terionisasi bertanggung jawab terhadap penghambatan konduksi saraf. 
Nilai konstanta disosiasi (pKa) dari tiap anestesi menunjukkan proporsi basa sebuah anestesi dan kationnya pada $\mathrm{pH}$ tertentu. Kebanyakan anestesi lokal memiliki $\mathrm{pH} 7,4$, dimana $80 \%$ atau lebih kation terionisasi terbentuk. Alkalisasi larutan anestesi dapat mempercepat onset aksi (Hruza, 2008).

Lidokain merupakan amida amino dengan pKa 7,9, dipasarkan dalam bentuk lidokain $\mathrm{Hcl}$ dan umumnya tersedia dalam larutan dengan pH 6,5 (Xia et al, 2001). Suasana asam dalam lidokain dibuat untuk meningkatkan stabilitas dan kelarutannya (Burns et al, 2005). Dengan meningkatkan $\mathrm{pH}$ hingga 7.4 dengan cara menambahkan larutan penyangga, bentuk molekul yang terionisasi yang mampu menembus membran sel neuron lebih banyak. Hal ini menyebabkan onset blokade saraf dan berkurangnya rasa sakit lebih cepat (Fatovich and Jacob, 1999).

Kebanyakan dermatologist menggunakan lidokain yang ditambahan dengan epinefrin (Burns et al, 2005). Penambahan epinefrin memiliki efek menguntungkan yaitu vasokonstriksi pembuluh darah yang dapat memperpanjang durasi anestesi, megurangi toksisitas, dan mengurangi perdarahan intraoperatif karena vasokonstriksi (Burns et al, 2005 and Hruza, 2008). Karena epinefrin hanya stabil untuk jangka waktu yang lama dalam lingkungan asam, $\mathrm{pH}$ lidokain premixeddengan epinefrin yang tersedia secara komersial lebih rendah dibandingkan dengan lidokain ( $\mathrm{pH} 3,3-5,5)$ dan karena itu lebih menyakitkan pada infiltrasi (Burns et al, 2005). Larutan asam tersebut tidak hanya lebih menyakitkan saat injeksi tetapi memperlambat timbulnya efek anestesi (Hruza, 2008). Untuk meminimalisasi nyeri terkait dengan $\mathrm{pH}$ yang rendah, larutan lidokain-epinefrin dapat baru dipersiapkan dengan dicampurkan sebelum prosedur pembedahan (Gursoy et al, 2007). Dengan cara mempersiapkan campuran baru lidokain dengan epinefrin, campuran tersebut memiliki $\mathrm{pH}$ yang lebih tinggi, dimana nyeri akan berkurang (Hruza, 2008). Alternatif lainnya adalah larutan yang telah tercampur sebelumnya (premixed) ditambahkan sodium bikarbonat sebagai penyangga dengan perbandingan 1:10. ${ }^{7}$ Pada penelitian kedua ini, kedua prosedur diatas akan dikerjakan dan dibandingkan tingkat nyeri yang ditimbulkan keduanya.

Laporan pertama mengenai penggunaan larutan penyangga untuk mengurangi nyeri saat infiltrasi anestesi lokal dilaporkan oleh Mc. Kay pada tahun 1987 dimana $61 \%$ pasien mengalami penurunan rata-rata sensasi nyeri (Fatovich and Jacob, 1999). Beberapa penelitian yang dilakukan oleh stewart, Cole dan kevin mengenai kadar epinefrin dalam larutan epinefrin dan lidokain yang ditambahkan larutan penyangga menunjukkan penurunan konsentrasi epinefrin sebanyak 25\% per minggu pada suhu kamar. Penelitian lain dilakukan oleh larson tentang efek refrigerator terhadap stabilitas larutan epinefrin dan lidokain yang ditambahkan larutan penyangga. Larutan lidokain 2\% dengan epinefrin $1: 100.000$ yang ditambahkan natrium bikarbonat disimpan dalam suhu kamar $\left(25^{\circ} \mathrm{C}\right)$ dan refrigerator $\left(0-4^{\circ} \mathrm{C}\right)$, kemudian menilai konsentrasinya menggunakan kromatografi, pada suhu kamar, konsentrasi epinefrin menurun $27 \%$ dalam minggu pertama dan $72 \%$ pada minggu kedua. Sebaliknya pada refrigerator, kadar epinefrin masih mencapai $99 \%$ pada minggu ke dua dan $82 \%$ pada minggu ke empat. Kadar lidokain pada penyimpana di refrigerator mencapai $99 \%$ pada minggu pertama dan $97 \%$ pada minggu kedua. Sehingga larutan epinefrin dengan lidokain yang ditambahkan larutan penyangga dapat disimpan sampai 2 minggu di dalam refrigerator (Shahwan, 2012).

Pada penelitian, skor VAS nyeri yang ditimbulkan pada penggunaan larutan buffered lebih rendah dibandingkan freshly mixed. Dengan $\mathrm{pH}$ yang lebih rendah pada larutan freshly mixed $(+6)$ dibandingkan dengan larutan yang ditambahkan larutan penyangga (+7 - 7.4) maka tidak mengherankan jika larutan freshly mixed cenderung lebih banyak menimbulkan nyeri. Nyeri yang ditimbulkan karena infiltrasi larutan anestesi sebagian besar disebabkan karena tingkat keasaman larutan anestesi. Keasaman larutan menyebabkan sensasi terbakar ketika masuk ke jaringan netral karena iritasi jaringan. Selain itu pada $\mathrm{pH}$ rendah, anestesi dalam bentuk aktifkurang, menyebabkan perpanjangan waktu sampai timbulnya anestesi. Stewart, Cole, dan Klein meneliti tentang pengurangan nyeri dan ambang $\mathrm{pH}$ dengan menambahkan natrium bikarbonat jumlah tertentu pada larutan anestesi. Mereka menemukan bahwa larutan anestesi tanpa penyangga $(\mathrm{pH} 4)$ dan larutan anestesi yang ditambahkanpH natrium bikarbonat $10 \mathrm{mEq} / \mathrm{L}(\mathrm{pH}$ 6.5) tidak berbeda bermakna dalam menimbulkan nyeri. Sedangkan penambahan natrium bikarbonat 
40mEq/L sampai dengan $\mathrm{pH} 7$ dan penambahan $100 \mathrm{mEq} / \mathrm{L}$ sampai dengan $\mathrm{pH} 7.3$ secara signifikan lebih tidak menimbulkan nyeri dibandingkan larutan tanpa penambahan natrium bikarbonat. Hasilnya menunjukkan bahwa penambahan larutan penyangga dengan $\mathrm{pH}$ masih kurang dari 7 tidak dapat menurunkan nyeri (Shahwan, 2012).

Meskipun hasil penelitian diatas tidak terlalu berbeda dalam hal nyeri yang ditimbulkan, tetapi larutan buffered cenderung tidak menimbulkan nyeri dibandingkan larutan freshly mixed lidokainepinefrin, sehingga lebih disarankan penggunaan larutan buffered pehakain. Kelemahan dari larutan freshly mixed lidokain dan epinefrin antara lain kesalahan dalam pencampuran dapat menyebabkan konsentrasi epinefrin lebih tinggi atau lebih rendah yang menyebabkan gangguan hemostasis, durasi aksi anestesi, toksisitas lidokain, dan efek kardio karena epinefrin (Shahwan, 2012).

\section{KESIMPULAN}

Pada penelitian yang dilakukan untuk membandingkan 2 metode untuk mengurangi nyeri infiltrasi anestesi lokal yang berhubungan dengan larutan anestesinya, freshly mixed lidokain-epinefrin lebih nyeri jika dibandingkan penggunaan pehakain yang ditambahkan dengan natrium bikarbonat sebagai larutan penyangga.

\section{DAFTAR PUSTAKA}

Leff DR, Nortley M, Dang V, Bhutiani RP,.The effect of local cooling on pain perception during infiltration of local anaesthetic agents, a prospective randomised controlled trial. Anaesthesia. 2007; 62: 677-82

Shahwan MA,.Prospective comparison between buffered $1 \%$ lidocaine-epinephrine and skin cooling in reducing the pain of local anesthetic infiltration. Dermatologic Surgery. 2012; 38:1654-9

Burns CA, Ferris G, Feng C, Cooper JZ, Brown MD, Decreasing the pain of local anesthesia: A prospective, double-blind comparison of buffered, premixed $1 \%$ lidocaine with epinephrine versus $1 \%$ lidocaine freshly mixed with epinephrine. Journal of The American Academy of Dermatology. 2005; 54: $128-31$

Willey A, Lee PK,. Cutaneous anesthesia. in : Roenigk RK, Ratz JL, Roenigk HH. Roenigk's Dermatologic Surgery Current Techniques in Procedural Dermatology. 3rd ed. New York. Informa Healthcare. 2007: 55-9
Bartfield JM, Kathleen M, Crisafulli, Robak RR, Salluzzo RF,. The effects of warming and buffering on pain of infiltration of lidocaine. Academic Emergency Medicine. 1995; 2: 254-8

Henning JS, Firoz BF,. The use of cooling device as an analgesic before injectable local anesthesia in the pediatric population. Dermatologic surgery. 2010; 36: 520-3

Gursoy A, Ertugrul DT, Sahin M, Tutuncu NB, Demirer AN, Demirag NG,. The analgesic efficacy of lidocaine/prilocaine (EMLA) cream during fine-needle aspiration biopsy of thyroid nodules. Turkish Journal of Endocrinology and Metabolism. 2007; 66: 691-4

Hruza GJ. Anesthesia. In : Bolognia JL, Jorizzo JL, Rapini RP,. Dermatology. 2nd edition. New York. Mosby Elsiever. 2008 : 2173-81

Xia Y, Chen E, Tibbits DL, Reilley TE, McSweeney TD. Comparison of effects of lidocaine hydrochloride, buffered lidocaine, diphenhydramine, and normal saline after intradermal injection. Journal of Clinical Anesthesia. 2001; 14: 339-43

Fatovich DM, Jacobs IG,. A randomized controlled trial of buffered lidocaine for local anesthetic infiltration in children and adults with simple lacerations. The Journal of Emergency Medicine. 1999; 17: 223-8 